P.D. Andrienko, O.V. Nemykina, A.A. Andrienko

\title{
HIGH CURRENT HARMONICS INFLUENCE ON THE CHOICE OF CONDUCTORS OF CRANE POWER SUPPLY SYSTEMS
}

Purpose. To study the effect of high current harmonics on the power and voltage losses in the conductive lines of the crane power supply systems and the development of an account method for this influence in practical calculations. Methodology. For research analytical methods and methods of simulation are used. Results. Analytical calculations have been performed for power losses and voltage losses for the conductors of crane power supply systems in the conditions of high harmonic generation for frequencycontrolled drives. Originality. For the first time, the authors have obtained the analytical expressions and graphical dependencies in relative units for practical calculations that allow determining the effect of high harmonics to the values of power losses and voltage losses for crane supply systems, while the parameters of steel conductors are nonlinear for load current and frequency. We have established that the values of power losses and voltage losses increase for crane power supply systems. It is shown that the power losses lead to a decrease the efficiency of crane supply systems up to $7 \%$, which must be taken into account when choosing electric drive systems and its payback period. Practical value. The obtained theoretical expressions can be used for calculations, design, optimization of crane power supply systems in terms of high harmonic generation. References 12 , tables 2 , figures 4 .

Key words: high harmonics, voltage losses, power losses, conductors, steel materials, aluminum tires, crane power systems.

У статті проведено дослідження впливу вищих гармонік струму на втрати напруги і потужності в струмопроводах систем живлення кранів. Отримані необхідні розрахункові співвідночення для визначення параметрів струмопроводів при наявності вищих гармонік. На прикладі найбільш розповсюджених частотно-регульованих приводів показано, цо в тролейних лініях зі сталевих матеріалів втрати напруги $і$ потужнності зростають до 4 разів $i$ до 1,43 рази, відповідно. Показано, цио наявність нелінійної залежності активного опору сталевих струмопроводів від струму навантаження $і$ частоти призводить до збільщення розрахункової величини втрат потужності в порівнянні 3 розрахунком через коефіцієнт спотворення струму. Встановлено, щцо величина tgф конструктивний показник струмопроводу. Наявність втрат потужності призводить до зниження ККД систем живлення кранів до $7 \%$, ще необхідно враховувати при виборі систем електроприводу $і$ його терміну окупності. Бібл. 12, табл. 2, рис. 4.

Ключові слова: вищі гармоніки, втрати напруги, втрати потужності, струмопроводи, сталеві матеріали, алюмінісві шини, системи живлення кранів.

В статье проведено исследование влияние высших гармоник тока на потери напряжения и мощности в токопроводах систем питания кранов. Получены необходмые расчетные соотночения для определения параметров токопроводов при наличии высших гармоник. На примере наиболее часто встречающихся частотно-регулируемых приводов показано, что в троллейных линиях из стальных уголков потери напряжения и мощности возрастают до 4 раз и до 1,43 раза, соответственно. Показано, что наличие нелинейной зависимости активного сопротивления стальных токопроводов от тока нагрузки и частоты приводит к увеличению расчетной величины потерь мощности по сравнению с расчетом через коэффициент искажения тока. Установлено, что величина использована как конструктивный показатель токопровода. Наличие потерь мощности приводит к снижению КПД систем питания кранов до 7 \%, что необходим учитывать при выборе систем электропривода и его срока окупаемости. Библ. 12 , табл. 2 , рис. 4.

Ключевые слова: высшие гармоники, потери напряжения, потери мощности, токопроводы, стальные уголки, алюминиевые шины, системы питания кранов.

Introduction. The main number of cranes is powered by alternating current of power frequency, which is decisive when choosing the type of used electric drives of cranes. The modern state of crane production industry is characterized by the introduction of semiconductor converters, significantly changing the quality of the crane electric drive, providing uniformly accelerated start and stop of mechanisms, which contributes to the reliability and durability of their mechanical structures and moving parts with significant energy saving [1-3]. In most cases, the advantage is given to the use of a variable frequency drive (VFD). The presence of semiconductor converters leads to the emergence of higher harmonics currents in the power supply system of cranes (PSSC), which in turn negatively affects the quality of electric power, electromagnetic compatibility, leads to a drop in voltage and power losses. When choosing a type of adjustable drive, an economic assessment is made by comparing their efficiency, cost, without taking into account losses in AC PSSC, which cause deterioration of the efficiency of the PSSC-VFD system [4-6].

The goal of the paper is to study the effect of higher current harmonics on the power losses and voltages in the conductors of the power supply systems of cranes and the development of methods for taking this influence into account in practical calculations.

Main materials of investigations.

1. Initial data. In existing practice, the $\mathrm{AC}$ power supply system is mainly used, and for the implementation of adjustable electric drives in crane installations, controlled rectifiers with DC motors or VFDs based on a two-stage frequency converter with an independent voltage inverter, having an uncontrolled, controlled or active bridge rectifier are used. The presence of bridge rectifiers leads to the appearance of higher harmonics of

(C) P.D. Andrienko, O.V. Nemykina, A.A. Andrienko 
$n=6 k \pm 1$ order $(k$ is the natural number $k=1,2,3,4, \ldots)$ in the AC network, which leads to an increase in the calculated current by an amount taken into account by the distortion coefficient $v$ or the harmonic factor $T H D_{I}$ in accordance with the requirements of International Standards IEEE 519-1992 or IEC 61000-3-12:2012 [5-7].

To assess the effect of higher harmonics in the AC PSSC using a two-stage frequency converter (FC), an equivalent circuit has been used (Fig. 1). The power source $(G)$ in the equivalent circuit is a symmetric system of limited power voltages. The power supply network is simulated by successive $R_{i} L_{i}$ chains.

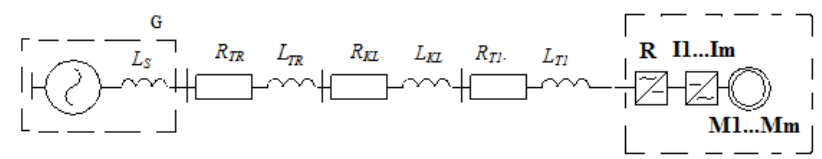

Fig. 1. Equivalent circuit of the AC PSSC

Each chain includes a corresponding inductance and a resistance: of a transformer $-R_{T R} L_{T R}$, of a cable line $R_{K L} L_{K L}$, of a section of a conductor $R_{T l} L_{T 1}$ - respectively to the first crane in the span.

When modernizing cranes, the VFD circuit with the common rectifier $(\mathrm{R})$ which is located on the crane is most often used. Depending on the type of crane, conductors of profiled steel, aluminum tires, flexible cables are used.

The following assumptions were made during the analysis:

- the constancy of the amplitude, the sinusoidal shape and symmetry of the three phase voltages on the secondary winding of the power transformer;

- the inductive and active resistances of all network elements, except the main conductor, are considered constant and independent on current;

- taking into account the influence of higher harmonics of the current is carried out by the simulation results for the PSSC with a VFD or by analytical relations, while the parameters of the conductor depend on the frequency and load current.

The choice of conductor sections is made according to the heating condition and is checked for voltage losses at the most distant point $[8,9]$.

The rated current of the conductor at non-sinusoidal load is determined based on the value of the calculated power $(P)$ by the relation [9]:

$$
I=\frac{P}{\sqrt{3} \cdot \lambda \cdot U_{n o m}}=\frac{P}{\sqrt{3} \cdot \cos \varphi_{1} \cdot v \cdot U_{n o m}},
$$

where $U_{\text {nom }}$ is the nominal voltage, $U_{\text {nom }}=380 \mathrm{~V}$; $\lambda, \cos \varphi_{1}, v$ are, respectively, the power factor for the nonsinusoidal circuit, the power factor of the main harmonic and the distortion factor.

For crane installations with controlled rectifiers and DC motors or two-stage frequency converters and VFD operating in intermittent mode, the input power factor is $\lambda=0.5 \div 0.6$ [2]. Ensuring electromagnetic compatibility (EMC) of the frequency converter (FC) with the supply network is achieved by installing an input smoothing reactor and/or an active rectifier. In this case, the input power factor of the main harmonic increases and can reach unity. Further studies were performed with $\cos \varphi_{1}=0.5 \div 1$ [4].

In the case of generation of higher harmonics, the calculated current of the conductor is determined by the relation [10]:

$$
I=\sqrt{\sum_{i=1}^{n} I_{n}^{2}}
$$

where $I_{n}$ is the value of the calculated current of the harmonic of the $n$-th order in conductors.

For a bridge rectifier, the relative values of the higher harmonics of the input current are determined from the relation:

$$
I_{n}^{*}=k_{n} \cdot \frac{I_{n}}{I_{1}}=k_{n} \cdot \frac{1}{n}=k_{n} \cdot \frac{1}{f_{n}^{*}},
$$

where $k_{n}$ is the coefficient taking into account the relative value of the amplitude of the $n$-th harmonic at different pulsations of the rectified current.

For the ideal rectifier $L_{d}=\infty, k_{n}=1$ the input current distortion factor $v=0.955$.

For a three-phase bridge rectifier in the input link of the FC and a capacitive filter, the values of higher harmonic currents were obtained by the simulation method [11], which was performed in the Matlab software package (Table 1).

The relation (2) in relative units with regard to (3) takes the form:

$$
I^{*}=\sqrt{\sum_{i=1}^{n}\left(k_{n} \cdot \frac{1}{f_{n}^{*}}\right)^{2}} .
$$

Table 1

Higher harmonic input current values
\begin{tabular}{|c|c|c|c|c|c|c|c|}
\hline \multirow{2}{*}{$I_{n} / I_{1}, \%$} & $n=5$ & $n=7$ & $n=11$ & $n=13$ & $n=17$ & $n=19$ & $v$ \\
\cline { 2 - 8 } & $38.3 \%$ & $2,2 \%$ & $7 \%$ & $3 \%$ & $3 \%$ & $2 \%$ & 0.926 \\
\hline$L_{d}=\infty, k_{n}=1$ & $20 \%$ & $14 \%$ & $9 \%$ & $7 \%$ & $6 \%$ & $5 \%$ & 0.955 \\
\hline$k_{n}$ & 1.91 & 0.87 & 0.77 & 0.42 & 0.5 & 0.4 & - \\
\hline
\end{tabular}

2. Determination of the parameters of conductors taking into account higher harmonics. A feature of conductors in terms of the generation of higher harmonics is the dependence of their active resistance on the magnetic permeability of the steel conductor and the frequency of the current.

The value of the active resistance of conductors made of corner steel is determined by the relations [9]:

$$
\left.\begin{array}{c}
R_{\omega}=K_{\omega} R_{0}=K_{\omega} \cdot \rho_{50} \cdot \frac{l}{S_{t}} \\
K_{\omega}=1+0,84 \cdot \beta_{w}, \text { at } \quad \beta_{w}<1 \\
K_{\omega}=0,758+\sqrt{1,34 \cdot \beta_{w}-0,83}, \text { at } \quad 1<\beta_{w}<3 \\
K_{\omega}=0,758+1,159 \beta_{w}, \text { at } \quad \beta_{w} \geq 3 \\
\beta_{w}=2 \cdot 10^{-2} \frac{S}{P} \cdot \sqrt{\frac{f}{\rho_{50}} \mu}
\end{array}\right\},
$$

where $S, P, l$ are, respectively, the section, $\mathrm{cm}^{2}$, perimeter, $\mathrm{cm}$, length, $\mathrm{m} ; R_{0}$ is the ohmic resistance of steel conductor to direct current, $\Omega / \mathrm{km} ; \mu$ is the relative magnetic permeability of steel conductor, which is determined by the curves [10], depending on the magnetic field strength $H=0.4 \cdot \pi \cdot I / P, \mathrm{~A} / \mathrm{cm} ; \rho_{50}$ is the resistivity to 
direct current, $\Omega \cdot \mathrm{mm}^{2} / \mathrm{m} ; I$ is the current in the conductor, $\mathrm{A}, \mathrm{S}_{t}$ is the section, $\mathrm{mm}^{2}$.

For trolley lines made of corner steel $50 \times 50 \times 5$ and $75 \times 75 \times 10$, according to the condition of permissible heating, the magnetic field strength values $H$ are within $6 \div 23.5 \mathrm{~A} / \mathrm{cm}$, which corresponds to the value $\mu=1500 \div 750$. According to relations (5), $\beta_{w}$ for the frequency $50 \mathrm{~Hz}$ (the first harmonic) takes the values $\beta_{w 1}=3.6 \div 3.2$ and $\beta_{w 1}=6.5 \div 5.8$, respectively. The specified values of $\beta_{w 1}$ correspond to the coefficient $K_{\omega 1}=5 \div 4.5$ and $K_{\omega 1}=8.25 \div 7.6$. Active resistance to alternating current $R_{\omega 1}=1.5 \div 1.4 \quad \Omega / \mathrm{km} \quad$ and $R_{\omega 1}=0.85 \div 0.78 \Omega / \mathrm{km}$ for corner steel $50 \times 50 \times 5$ and
$75 \times 75 \times 10$, while the ohmic resistance of the corners to direct current is 5 and 8.25 times less, respectively (Table 2).

The value of the inductive resistance of trolley lines of corner steel for the first harmonic is determined by the relation [9]:

$$
X_{\omega 1}=X^{1}+X^{11} \approx X^{1}+0,56 R_{\omega 1},
$$

where $X^{1}$ and $X^{11}$ are the internal and external inductive resistances of trolley lines, respectively.

The values of active and internal inductive resistances of trolley lines made of corner steel $R_{\omega 1}$ and $X^{11}$, according to relations (5), (6), depend on the load current and frequency. The value of the internal inductive resistance $X^{1}$ does not depend on the load current.

Table 2

Parameters of the investigated conductors

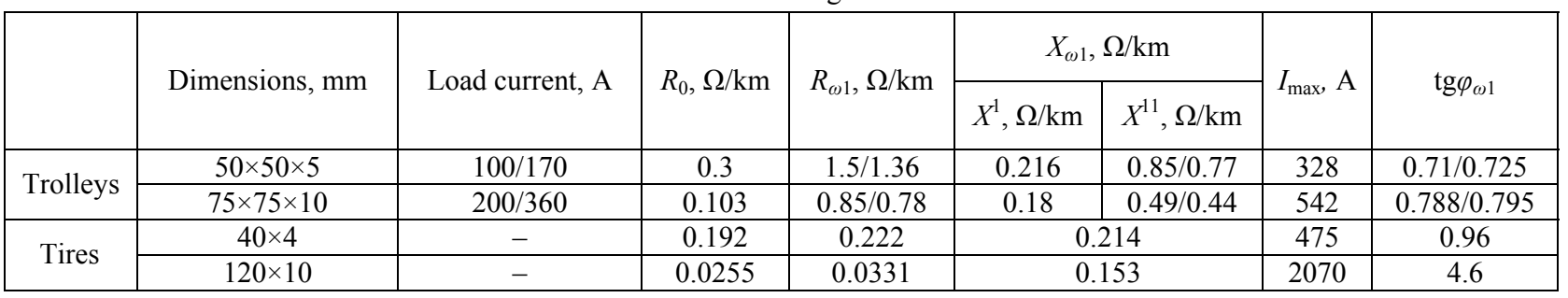

The parameters of the most used conductors in the form of steel trolley lines and aluminum tires for the first harmonic are given in Table 2. Analysis of data of Table 2 shows that for trolley lines made of corner steel, $\operatorname{tg} \varphi_{\omega 1}$ varies in the range of $0.71 \div 0.795$ and practically does not depend on their section; with a slight error, $\operatorname{tg} \varphi_{\omega 1} \approx 0.75=$ $=$ const can be taken, while for tires, $\operatorname{tg} \varphi_{\omega 1}$ increases with increasing section of tires.

Internal inductive resistance for the corners of $50 \times 50 \times 5$ and $75 \times 75 \times 10$ is in the range of $0.216 \div 0.18$ $\Omega / \mathrm{km}$ and with a slight error $X^{1} \approx 0.195=$ const can be taken.

When generating harmonic currents $n \geq 5$ in the steel conductor, the coefficient $\beta_{w}$, expression (5), therefore, with an accuracy of up to $10 \%, K_{\omega n} \approx 1.159 \cdot \beta_{w n}$ can be taken.

The relative value of the active resistance of the conductor for the harmonics of the $n$-th order, taking into account expressions (5):

$$
R_{\omega n}^{*}=\frac{R_{\omega n}}{R_{\omega 1}}=\frac{K_{\omega n}}{K_{\omega 1}} \approx \frac{\beta_{w n}}{\beta_{w 1}}=\sqrt{f_{n}^{*}},
$$

where $f_{n}^{*}=f_{n} / f_{1}$ is the relative frequency of the harmonic of the $n$-th order; $f_{n}, f_{1}$ are the frequency of the harmonic of the $n$-th order and the fundamental frequency, respectively.

Active and inductive resistance of trolley lines for the harmonics of the $n$-th order:

$$
\begin{gathered}
R_{\omega n}=R_{\omega 1} \cdot \sqrt{f_{n}^{*}} \\
X_{\omega n}=X_{\omega 1} \cdot f_{n}^{*}=\left(X^{1}+0,56 R_{\omega 1} \cdot \sqrt{f_{n}^{*}}\right) \cdot f_{n}^{*} .
\end{gathered}
$$

Using relations (8) and (9) we express the value:

$$
\operatorname{tg} \varphi_{\omega n}=\frac{X_{\omega n}}{R_{\omega n}}=\frac{\left(0,195+0,56 \cdot R_{\omega 1} \cdot \sqrt{f_{n}^{*}}\right) \cdot f_{n}^{*}}{R_{\omega 1} \cdot \sqrt{f_{n}^{*}}} .
$$

At $f_{n}^{*}>5$, the value of the internal inductive resistance of the trolley lines is small compared with the external inductive resistance, therefore, with enough accuracy for practice, it is possible to use the relation:

$$
\operatorname{tg} \varphi_{\omega n}=\operatorname{tg} \varphi_{\omega 1} \cdot f_{n}^{*} \approx 0,56 \cdot f_{n}^{*} .
$$

Note that for aluminum tires and copper conductors in the frequency range under study, the manifestation of the skin effect is insignificant, therefore the tires resistance is constant $R_{\omega n}=R_{\omega 1}$.

The $\operatorname{tg} \varphi_{\omega n}$ value for harmonics of the $n$-th order of aluminum tires and copper conductors is determined by the relation $\operatorname{tg} \varphi_{\omega n}=\operatorname{tg} \varphi_{\omega 1} \cdot f^{*}$.

3. Determination of voltage losses in conductors taking into account higher harmonics. In the general case, the voltage losses are determined by the relation [10]:

$$
\Delta U=\sqrt{\sum_{i=1}^{n} \Delta U^{2} n}
$$

where $\Delta U_{n}$ are the voltage losses for harmonics of the $n$ th order in conductors:

$$
\begin{aligned}
& \Delta U_{n}=\frac{\sqrt{3} k_{\max } \cdot I_{n} \cdot\left(R_{\omega n} \cdot l \cdot \cos \varphi_{1}+X_{\omega n} \cdot l \cdot \sin \varphi_{1}\right)}{U_{n o m}} \cdot 100= \\
& =\frac{\sqrt{3} k_{\max } \cdot I_{n} \cdot R_{\omega n} \cdot l\left(\cos \varphi_{1}+\operatorname{tg} \varphi_{\omega n} \cdot \sin \varphi_{1}\right)}{U_{n o m}} \cdot 100,
\end{aligned}
$$

where $I_{n}, \varphi_{1}$ are the current value of the $n$-th harmonic and the shift angle of the main harmonic, respectively; $l$ is the conductor length; $k_{\max }$ is the coefficient taking into account the increase in peak current relative to the calculated value of current.

The value of $\cos \varphi_{1}$ is determined by the switching angle $\gamma$ for rectifiers installed in the input link of the FC.

Using the previously accepted assumptions, we transform the relation (12). For steel conductors, the relation takes the form: 


$$
\begin{aligned}
& \Delta U^{*}=\frac{\sqrt{\sum_{i=1}^{n} \Delta U^{2} n}}{\Delta U_{1}}= \\
& =\sqrt{1+\sum_{k=1}^{n=6 k \pm 1}\left(k_{n}\right)^{2} \frac{1}{f_{n}^{*}}\left(\frac{\cos \varphi_{1}+0,56 \cdot f_{n}^{*} \cdot \sin \varphi_{1}}{\cos \varphi_{1}+\operatorname{tg} \varphi_{\omega 1} \cdot \sin \varphi_{1}}\right)^{2}}
\end{aligned}
$$

For aluminum tires the relation (15) takes the form: $\Delta U^{*}=$

$$
\sqrt{1+\sum_{k=1}^{n=6 k \pm 1}\left(k_{n}\right)^{2} \frac{1}{\left(f_{n}^{*}\right)^{2}}\left(\frac{\cos \varphi_{1}+\operatorname{tg} \varphi_{\omega 1} \cdot f_{n}^{*} \cdot \sin \varphi_{1}}{\cos \varphi_{1}+\operatorname{tg} \varphi_{\omega 1} \cdot \sin \varphi_{1}}\right)^{2}} .
$$

In the study of voltage losses in terms of the generation of higher harmonics, it was found that their value is determined mainly by the product $\operatorname{tg} \varphi_{\omega} 1 \cdot f_{n}^{*} \cdot \sin \varphi_{1}$, which is part of the function $f(\varphi)=$ $=\left(\cos \varphi_{1}+\operatorname{tg} \varphi_{\omega 1} \cdot f_{n}^{*} \cdot \sin \varphi_{1}\right)$.

The dependencies of the function $f(\varphi)=\left(\cos \varphi_{1}+\operatorname{tg} \varphi_{\omega 1} \cdot \sin \varphi_{1}\right)$ for the main harmonic are shown in Fig. 2.
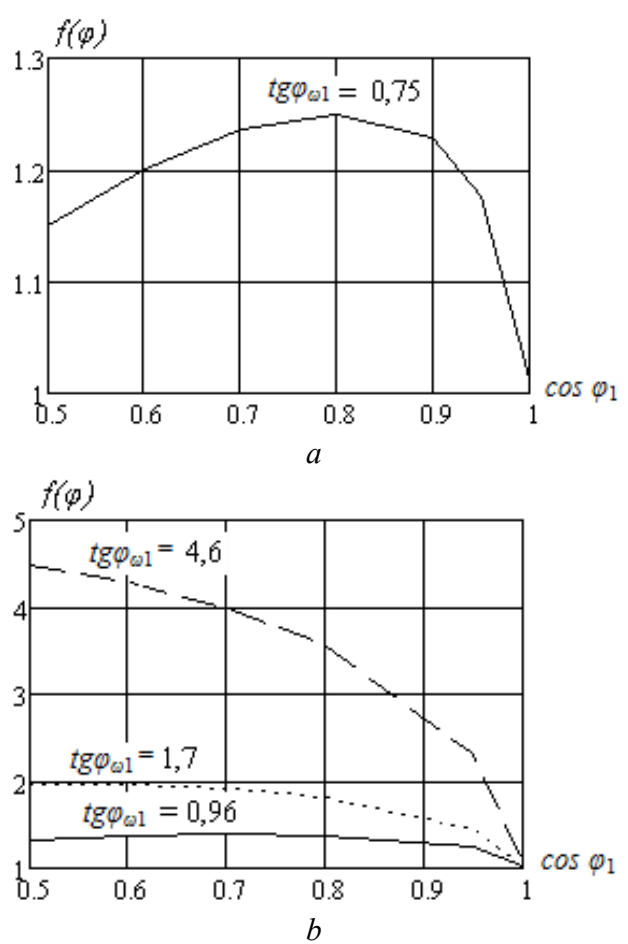

Fig. 2. Dependencies $f(\varphi)=\left(\cos \varphi_{1}+\operatorname{tg} \varphi_{\omega 1} \cdot \sin \varphi_{1}\right)$ for conductors made by trolley lines $(a)$ and tires $(b)$

For trolley lines $\left(\operatorname{tg} \varphi_{\omega 1}=0.75\right)$ at changes $0.6<\cos \varphi_{1}<0.95$, the function $f(\varphi)$ can be approximated with enough accuracy for practice by the value $f(\varphi) \approx 1.2$, which greatly simplifies the calculations. The maximum value of the function $f(\varphi) \approx 1.25$ takes at $\cos \varphi_{1}=0.8$.

When using tires $\operatorname{tg} \varphi_{\omega 1}$ varies in the range of $0.96 \div 4.6$

For $\operatorname{tg} \varphi_{\omega 1}=0.96$, at $0.5<\cos \varphi_{1}<0.95$, the values $f(\varphi) \approx 1.37$. For $\operatorname{tg} \varphi_{\omega 1} \geq 1.7$, which is typical for tires of $50 \times 6 \mathrm{~mm}$ and more, the function monotonously increases with decreasing $\cos \varphi_{1}$. The minimum value the function $f(\varphi)$ takes at $\cos \varphi_{1}=1$.

The dependencies of the relative values of $\Delta U^{*}=f\left(\cos \varphi_{1}\right)$ for trolley lines and tires, calculated by relations (15) and (16), are shown in Fig. 3. Analysis of dependencies shows that at the same harmonic composition of the current, the relative value of the voltage losses in conductors of the steel corner is much higher than in tires. This is explained by the fact that for trolley lines the component $\Delta U_{n}^{*} \mathrm{n}$ is inversely proportional to $f_{n}^{*}$, and for tires to $\left(f_{n}^{*}\right)^{2}$. When reducing the shift coefficient to $\cos \varphi_{1}=0.5$, which is typical for controlled rectifiers, voltage losses increase 4 times for steel corners, and 2.5 times for tires.
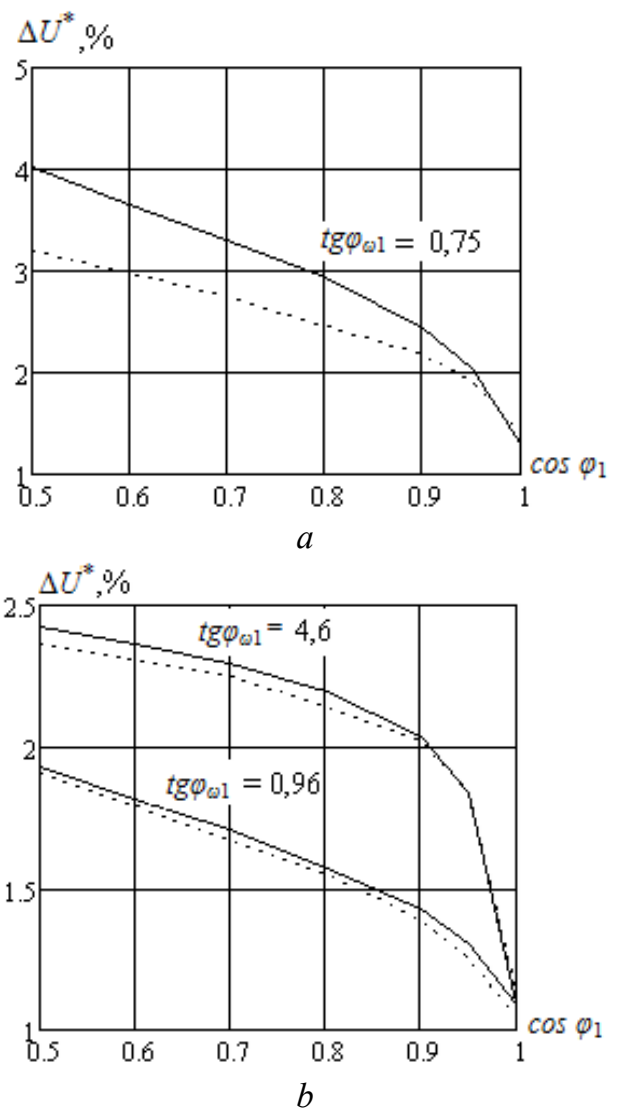

Fig. 3. Dependencies $\Delta U^{*}=f\left(\cos \varphi_{1}\right)$ for conductors at $v=0.955$ (solid line) and $v=0.926$ (dotted line), made by trolley lines $(a)$ and tires $(b)$

This circumstance confirms the need to take into account the effect of higher harmonics when calculating the voltage losses.

The decrease in the distortion coefficient $v$ from 0.955 to 0.926 leads to a decrease in the voltage losses in the conductors, which indicates a non-linear dependence of $\Delta U^{*}$ on the amplitudes of the harmonic components of the current curve.

Therefore, when designing PSSCs that have semiconductor converters (rectifiers, FCs, voltage regulators), it is necessary to determine the harmonic composition by simulation modeling. Dependencies of $\Delta U^{*}$ have a number of characteristic points.

For conductors of corner steel, the relation (15) takes the form:

- at $v \leq 0.95$ and $\cos \varphi_{1}=1$

$$
\Delta U^{*}=\sqrt{1+\sum_{k=1}^{n=6 k \pm 1}\left(k_{n}\right)^{2} \frac{1}{f_{n}^{*}}},
$$




$$
\begin{aligned}
& \text { - at } \sin \varphi_{1}=1\left(\cos \varphi_{1}=0\right) \\
& \Delta U^{*}=\sqrt{1+\sum_{k=1}^{n=6 k \pm 1}\left(k_{n}\right)^{2},} \\
& \text { - at } k_{n}=1, \Delta U^{*} \rightarrow \sqrt{2} .
\end{aligned}
$$

The absolute value of the voltage losses is proportional to the calculated value of $I_{n}$ and the active resistance $R_{\omega n}$ according to (13). Since the tire resistance is less than steel corners one, at an equal value of the calculated current, the absolute value of the voltage drop in the tires is significantly less.

Note that the use of cable conductors for powering portal [12] and gantry cranes provides a significant reduction in voltage losses due to their relatively low $\operatorname{tg} \varphi_{\omega 1}$.

4. Determination of power losses in conductors taking into account higher harmonics. The power losses in the AC conductors for the first harmonic is determined by the relation [9]:

$$
\Delta P_{1}=3\left(I_{1}\right)^{2} R_{\omega_{1}}=3\left(\frac{P}{\sqrt{3} \cdot \cos \varphi_{1} \cdot U_{n o m}}\right)^{2} R_{\omega_{1}},
$$

where $I_{1}$ is the calculated value of the main harmonic current.

The relative value of the additional losses in the $\mathrm{AC}$ conductor in the conditions of generation of higher harmonics is determined from the relationship:

$$
\Delta P_{\Sigma}^{*}=\frac{\sum_{k=1}^{n=6 k \pm 1} \Delta P_{n}}{\Delta P_{1}}=\sum_{k=1}^{n=6 k \pm 1} R_{\omega n}^{*} \cdot\left(I_{n}^{*}\right)^{2},
$$

where $\Delta P_{1}$ are the power losses at the main harmonic in the $\mathrm{AC}$ conductor.

Taking into account expressions (3) and (7), the relative value of the additional losses in the conductor:

$$
\Delta P_{\sum}^{*}=\sum_{k=1}^{n=6 k \pm 1} k_{n} \cdot \frac{\sqrt{f_{n}^{*}}}{\left(f_{n}^{*}\right)^{2}} .
$$

Relative total losses taking into account the first harmonic:

$$
\Delta \Sigma P^{*}=\left(1+\Delta P_{\Sigma}^{*}\right)
$$

After summing up the series (21) for the conductor under consideration at $v=0.955$, we obtain the value $\Delta P_{\Sigma}^{*}=0.26$. The relative total losses $\Delta \Sigma P^{*}=1.26$ according to (22).

When calculating using the distortion coefficient $v$, the relative total losses:

$$
\Delta \Sigma P^{*}=\Delta P_{1} / v^{2}=1 / v^{2}=1 / 0.95=1.11 \text {. }
$$

The resulting value by the ratio $(22) 1.26 / 1.11=1.135$ times more compared with the well-known conventional approach.

When the distortion coefficient $v=0.926$ according to the data of Table 1 relative value of additional losses according to the expression (21) $\Delta P_{\Sigma}^{*}=0.436$. Relative total losses taking into account the main harmonic $\Delta \Sigma P^{*}=1.436$

When calculating using the distortion factor: $\Delta \Sigma P^{*}=1 / 0.93^{2}=1.15$.

The value of the relative total losses increase by $1.436 / 1.15=1.25$ times.
In conductors made of aluminum tires (for example, for powering portal cranes), the active resistance value is not significantly dependent on the presence of higher harmonics, therefore, with enough accuracy for practice, power losses can be determined using the standard technique: $\Delta \Sigma P^{*}=\Delta P_{1} / v^{2}=1 / v^{2}$.

This circumstance confirms the need to take into account the effect of higher harmonics when calculating power losses in conductors.

5. Influence of power losses in conductors on the efficiency of power supply systems of cranes. Figure 4 shows the dependence of the relative value of the main harmonic power losses $\left(\Delta P_{1}{ }^{*}=\Delta P_{1} / P_{1}\right)$ in conductors $100 \mathrm{~m}$ long at load currents and the parameters of the conductors given in Table 2 when changing the values of $\cos \varphi_{1}=0.5 \div 1$.

The dependency analysis (see Fig. 4) shows that at $\cos \varphi_{1}=1$ and $l=100 \mathrm{~m}$, the relative power losses in the trolley lines are $5 \%$ and $6.1 \%$, respectively for the corners $50 \times 50 \times 5$ and $75 \times 75 \times 10$, for aluminum tires $1.4 \%$ and $1.03 \%$, respectively, for sections $40 \times 4 \mathrm{~mm}$ and $120 \times 10$ $\mathrm{mm}$. At $\cos \varphi_{1}=0.5$, the relative losses in trolley lines are $20 \%$ and $25 \%$, respectively for $50 \times 50 \times 5$ and $75 \times 75 \times 10$, the losses in tires are $4.1 \%$ and $5.5 \%$, respectively for sections $120 \times 10 \mathrm{~mm}$ and $40 \times 4 \mathrm{~mm}$.
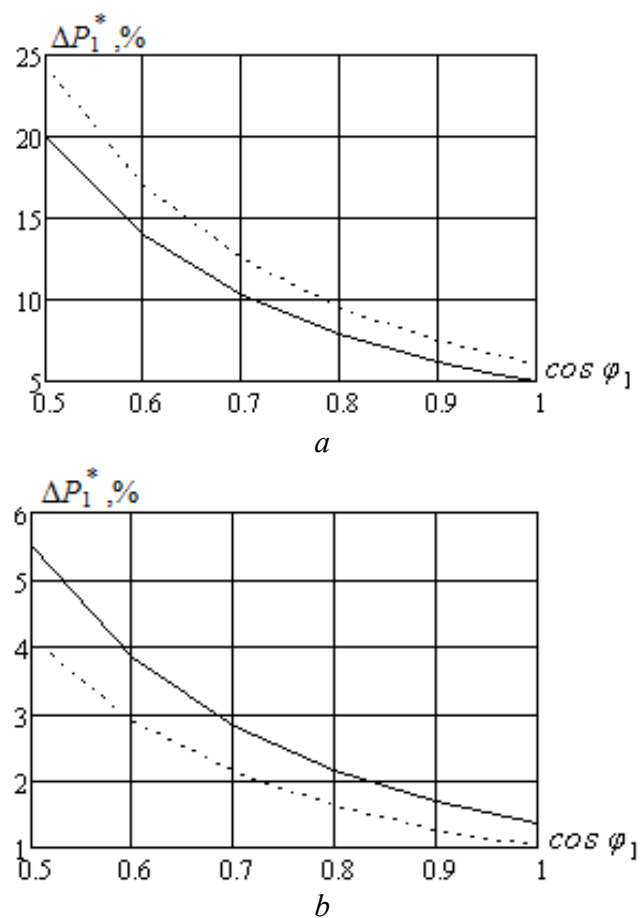

Fig. 4. Dependencies $\Delta P_{1}{ }^{*}=f\left(\cos \varphi_{1}\right)$ for conductors made by trolley lines $(a) 50 \times 50 \times 5 \mathrm{~mm}$ at $P=59 \mathrm{~kW}$ (solid line) and $75 \times 75 \times 10 \mathrm{~mm}$ at $P=125 \mathrm{~kW}$ (dotted line); as well as made by tires $(b), 40 \times 4 \mathrm{~mm}$ at $P=100 \mathrm{~kW}$ (solid line) and $120 \times 10 \mathrm{~mm}$ at $P=500 \mathrm{~kW}$ (dotted line)

Thus, the relative losses in trolley lines increase by 3-3.5 times as compared with tires. At real lengths of 60-70 $\mathrm{m}$ and the location of the nodes for feeding trolley lines, the losses in them are 3-5\%, depending on the angle of the corner. Taking into account the additional losses from higher harmonics and real power factors, the power losses increase to $4.5-7 \%$. 
At tire lengths up to $300 \mathrm{~m}$, which is typical of gantry cranes, the losses amount to $4.2 \%$, taking into account the additional losses the power losses increase to $5 \%$.

This circumstance leads to a decrease in the efficiency of the PSSC with VFD, which must be taken into account when justifying the payback period of the electric drive system.

Conclusions.

1. The presence of higher harmonics in the conductors of power supply systems of cranes at changing values of $\cos \varphi_{1}=0.5 \div 0.95$ causes:

- an increase in voltage losses of 1.8-2.5 times as compared with sinusoidal current for tires $\operatorname{tg} \varphi_{\omega 1}$ and of 3.2-4 times for steel trolley lines;

- an increase in power losses of 1.26-1.43 times compared with sinusoidal current at using steel trolley lines.

2. It is shown that the decisive parameter affecting the voltage and power losses is the tangent of the conductor $\operatorname{tg} \varphi_{\omega 1}$, which can be used as a design parameter of the conductor. Conductors with minimal $\operatorname{tg} \varphi_{\omega 1}$ have minimal losses.

3. The presence of power losses in conductors made by trolley lines, taking into account the additional losses leads to a decrease in the efficiency of power supply systems of cranes to $4.5-7 \%$ at using trolley lines and up to $5 \%$ when using tires, which must be taken into account during the feasibility study of electric drive systems. The presence of additional losses from higher harmonics in the power systems of $\mathrm{AC}$ cranes leads to an increase in the cost of the implementation of conductors.

\section{REFERENCES}

1. Gerasimyak R.P., Busher V.V., Kalinin A.G. Elektroprivody i sistemy upravleniia kranovykh mekhanizmov [Electric drives and control systems of crane mechanisms]. Odessa, Science and Technology Publ., 2014. 202 p. (Rus).

2. Volkov I.V. The new concept of building power circuits of frequency-controlled asynchronous electric drives. Technical electrodynamics, 1999, no.4, pp. 21-26. (Rus).

3. Tishchenko V.N., Kolotilo V.I. The current state of electric lifting mechanisms. Transactions of NTU «KhPI». Chapter «Problems of automated electric drive». Theory and practice, 2005, no.45, pp. 303-306. (Rus).
4. Nemykina O.V. The choice of the power supply system of cranes with variable frequency drive. Electrotechnic and computer systems, 2015, no.19, pp. 54-57. (Rus).

5. IEEE 519-1992. IEEE Recommended Practices and Requirements for Harmonic Control in Electrical Power Systems, USA, New York, 1993.

6. IEC 61000-3-12:2012. Electromagnetic compatibility (EMC) of technical equipment. International Standard, 2012.

7. IEC 61000-3-12:2004. Limitation of emission of harmonic currents in low voltage power supply systems for equipment with rated current greater than $16 \mathrm{~A}$ per phase. International Standard, 2004.

8. Rudnitskiy V.G. Vnutrishnotsehove elektropostachannya. [Innerly electric power supply]. Sumy, University Book Publ., 2007. 280 p. (Ukr).

9. Spravochnik energetika promyishlennyih predpriyatiy. T.1. Elektrosnabzheniye. [Reference energy industry enterprises. Vol.1. Power supply]. Moscow, Leningrad, Gosenergoizdat Publ., 1961. 840 p. (Rus).

10. Zhezhelenko I.V., Saenko Yu.L. Pokazateli kachestva $i$ ih kontrol na promyishlennyih predpriyatiyah [Quality indicators and their control at industrial enterprises]. Moscow, Energoatomizdat Publ., 2000. 252 p. (Rus).

11. Andrienko P.D., Nemykina O.V., Andrienko D.S. Electromagnetic compatibility of power supply systems of cranes with variable frequency drives. Electrical Engineering and Electromechanics. Special edition of the XXII scientifictechnical conference Power electronics and energy efficiency, 2016/4(2), vol.2, pp. 109-112. (Rus).

12. Radimov S.N. Experimental determination of the actual electrical parameters of crane busbars - an informational basis for optimizing their operation. Bulletin of the Odessa National Maritime University, 2001, no.7, pp. 161-168. (Rus).

Received 07.01.2019

P.D. Andrienko ${ }^{1}$, Doctor of Technical Science, Professor, O.V. Nemykina ${ }^{1}$, Candidate of Technical Science, Associate Professor,

A.A. Andrienko ${ }^{1}$, Postgraduate Student,

${ }^{1}$ Zaporozhye National Technical University, 64, Zhukovsky Str., Zaporozhye, 69063, Ukraine, e-mail: andrpd@ukr.net, olganemikina@ukr.net

\section{How to cite this article:}

Andrienko P.D., Nemykina O.V., Andrienko A.A. High current harmonics influence on the choice of conductors of crane power supply systems. Electrical engineering \& electromechanics, 2019, no.3, pp. 24-29. doi: 10.20998/2074272X.2019.3.04. 